\title{
Geographical range expansion of Nitzschia volvendirostrata Ashworth, Dąbek \& Witkowski, 2016 (Bacillariophyta: Bacillariaceae) based on morphological and molecular analysis
}

\author{
María Concepción Lora-Vilchis ${ }^{1}$, Gopal Murugan ${ }^{1}$ and Francisco Omar López-Fuerte $2^{2^{*}}$
}

\begin{abstract}
In diatoms the use of molecular tools to corroborate traditional (morphological) identification offers a new perspective in the field of biogeography. This manuscript reports the first record of the raphid pennate diatom Nitzschia volvendirostrata along the coast of Mexico, which in turn represents an expansion of the geographic range along the American continent. The cells were isolated from benthic samples taken from Balandra lagoon, La Paz, Baja California Sur, Mexico and cultured as a monoclonal culture. Morphology and morphometry of the diatom obtained from light and electron microscopy reveal that they correspond to the original description of $\mathrm{N}$. volvendirostrata and also its chloroplast sequences, rbcL and psbC, showed 98.7 to $100 \%$ similarity and a close phylogenetic relationship with $\mathrm{N}$. volvendirostrata. The reported places for this taxon show that it has a tropicaltemperate biogeographical affinity.
\end{abstract}

Keywords: Baja California Sur, Balandra lagoon, Benthic diatom, First record, Mexico

\section{Introduction}

For diatoms, the accessibility and advances of electron microscopy and molecular tools for identifying and describing species has opened this up even to non-specialists, and nowadays this approach is considered as classic (Medlin 2018; Blanco 2020). Also, the process of isolation, culture and maintenance of diatom strains in the collections of microalgae could be used as complementary to microscopy and molecular tools to obtain accurate and reliable information on the identity of a taxon. This information could also be used to explore autoecological

\footnotetext{
* Correspondence: folopez@uabcs.mx

2Departamento Académico de Ciencias Marinas y Costeras, Universidad Autónoma de Baja California Sur, Carretera al Sur, km. 5.5, La Paz, Baja California Sur, México C.P. 23080

Full list of author information is available at the end of the article
}

information, particularly about the certainty of geographic distribution of the species as well as the knowledge of the biological, physiological, biochemical and biotechnological potential use of a species (Scholz and Liebezeit 2012, 2013).

For the Mexican coasts, 501 new records of benthic diatoms have been reported from 1999 to 2020, which includes almost unexplored sites such as the Revillagigedo Archipelago (Siqueiros-Beltrones et al. 2019). Also, a substrate considered exotic (stone fish skin Scorpaena mystes) presented a new species of benthic diatom for the California Gulf (López-Fuerte and SiqueirosBeltrones 2018). A second new species of diatom was described from a sample isolated and cultured from a hypersaline evaporation pond at the Guerrero Negro Saltworks, Baja California Sur (López-Fuerte et al. 2020).

(c) The Author(s). 2021 Open Access This article is licensed under a Creative Commons Attribution 4.0 International License, which permits use, sharing, adaptation, distribution and reproduction in any medium or format, as long as you give

appropriate credit to the original author(s) and the source, provide a link to the Creative Commons licence, and indicate if changes were made. The images or other third party material in this article are included in the article's Creative Commons licence, unless indicated otherwise in a credit line to the material. If material is not included in the article's Creative Commons licence and your intended use is not permitted by statutory regulation or exceeds the permitted use, you will need to obtain permission directly from the copyright holder. To view a copy of this licence, visit http://creativecommons.org/licenses/by/4.0/ 
Among the benthic diatoms, the pennates are the more common and the genus Nitzschia is very common in marine and freshwater environments (Lowe 2003; LópezFuerte et al. 2010). However, this genus includes both benthic and planktonic species (Lundholm and Moestreup 2000). Nitzschia is the second largest diatom genus after Navicula and is known for its taxonomic difficulty, which could also be related to the high number of species names i.e. 1308; of these almost $64 \%$ (841) has been accepted taxonomically, but many of the difficult ones remain to be identified (Mann 1986; Guiry and Guiry 2021).
In 2016 Ashworth, Dąbek and Witkowski described a new species of diatom Nitzschia volvendirostrata based on two strains, one from Saudi Arabia (strain KSA0039) and another one from Mozambique (strain SZCZP36) (Witkowski et al. 2016). They used two genetic markers of chloroplast, $r b c L$ and $p s b C$, in combination with light and scanning electron microscopy to identify this taxon.

In this paper we report the first record of $N$. volvendirostrata on the American continent with a sample collected from the coastal lagoon of Balandra in the Gulf of California located along the southern coast of the Baja California

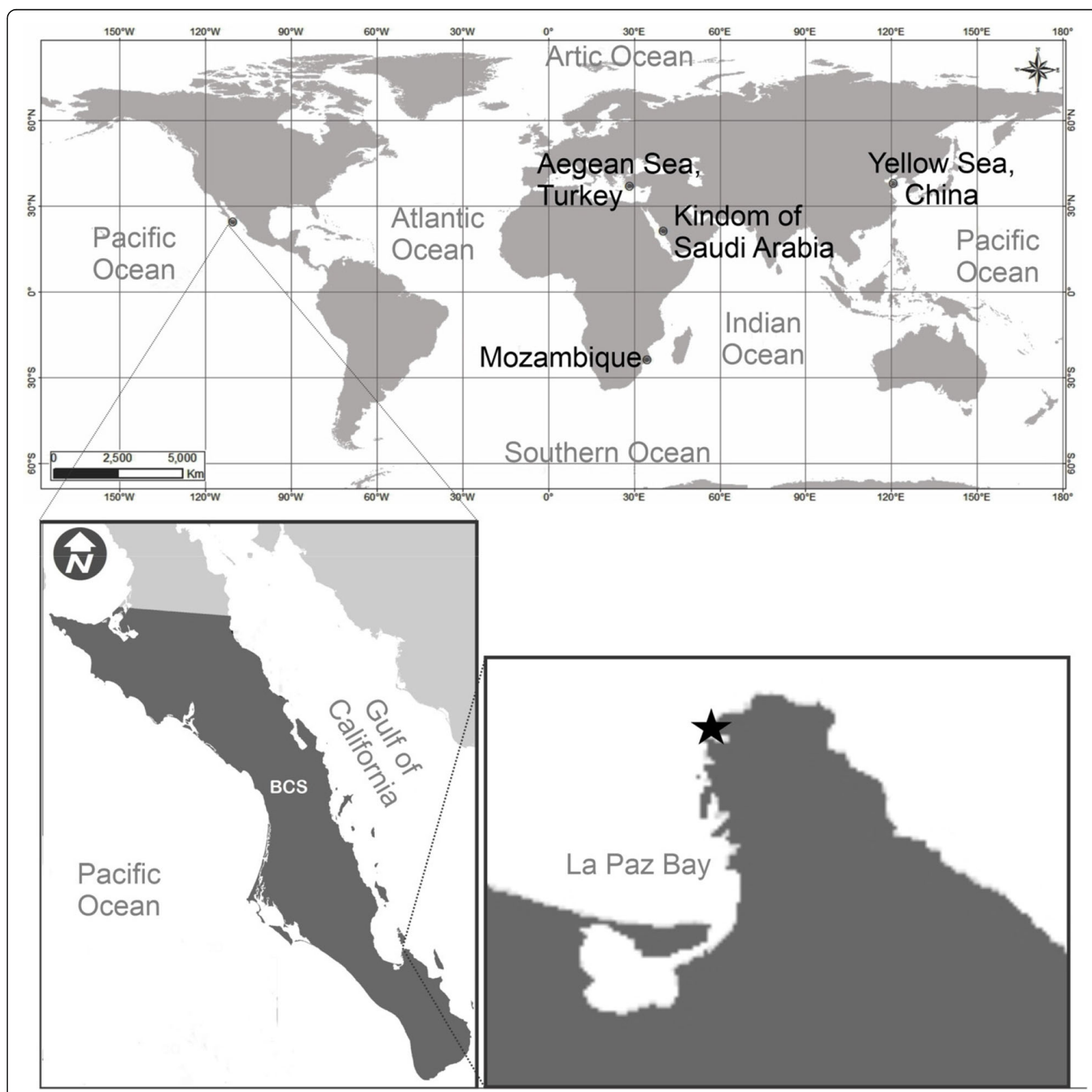

Fig. 1 Current records of Nitzschia volvendirostrata worldwide and new record along the American continent (Balandra lagoon*) 
Peninsula. The identity of the taxon was determined by light and scanning electron microscopy and the genetic markers $r b c L$ and $p s b C$ (Witkowski et al. 2016).

\section{Material and methods}

Benthic samples were taken from the Balandra lagoon $24^{\circ} 19^{\prime} 9.01^{\prime \prime} \mathrm{N} 110^{\circ} 19^{\prime} 18.17^{\prime \prime}$ W, La Paz, Baja California Sur (Fig. 1) in December 2018 and brought to the laboratory in conical tubes and filtered using a $30 \mu \mathrm{m}$ Nitex mesh. Cells were isolated by dilution 1:50 in $\mathrm{f} / 2$ media and streaked in marine agar plates with $\mathrm{f} / 2$ media with silicates (Guillard 1975). Colonies formed from single cells were isolated under a low magnification and were transferred to wells containing a small volume of media. Later the cells were cultured in test tubes with 5 $\mathrm{ml}$ of media. Using a light microscope, we examined the unialgal culture of isolated cells and integrated the monoclonal cultures into the Culture Collection of Microalgae of CIBNOR under the catalogue number CIB 113 (https://www.cibnor.gob.mx/investigacion/ colecciones-biologicas/coleccion-de-microalgas). For microscopic and molecular analysis, we cultured cells in $500 \mathrm{ml}$ flasks containing $250 \mathrm{ml}$ of media under the culture conditions $25 \pm 1{ }^{\circ} \mathrm{C}, 40 \mu \mathrm{M} \cdot \mathrm{m}^{-2} \cdot \mathrm{s}^{-1}, 12: 12 \mathrm{~h}$ photoperiod and 35 PSU; at exponential stage the cultures were divided into separate samples for each kind of analysis. The cultures were done by triplicate to obtain three samples of the same stage and culture conditions.

Live and cleaned cells were observed in a microscope Zeiss Axio Lab A1 and photographs were taken with a Canon EOS Rebel T5i camera (Fig. 2a-b). The cells were prepared for scanning electron microscopy (SEM) as indicated by López-Fuerte et al. (2020); in brief, the organic matter was eliminated from cell walls by a heatassisted oxidation with nitic acid, then the cells were washed in distilled water until reaching a neutral $\mathrm{pH}$. SEM photographs of the cells (Figs. $2 c-d$ and 3) were taken with a Hitachi SU3500 electron microscope, operating at $10 \mathrm{kV}$ and a $6-\mathrm{mm}$ working distance. A coverslip holding the cells was attached to a $32-\mathrm{mm}$ aluminum stub using conductive carbon tape and coated with around $15 \mathrm{~nm}$ of gold in a Hummer 6.2 sputtering unit.

Morphological characteristics, i.e. length, width, density of fibulae, striae and areolae, were measured by light
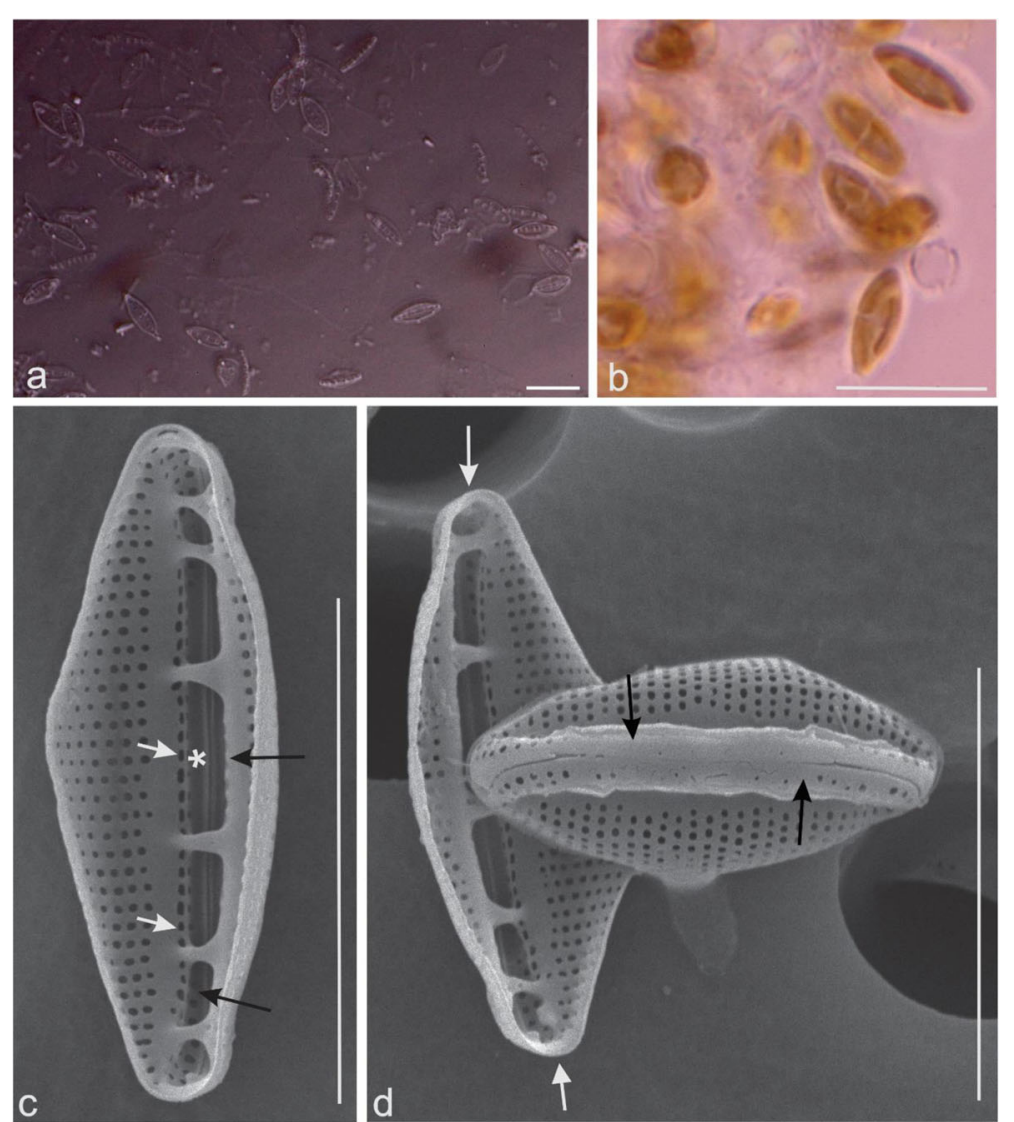

Fig. 2 Nitzschia volvendirostrata. a Cleaned specimens, b Live cell showing plastids, c Internal view of the valve, d External and internal view of the valve (vertical) and frustule (horizontal). $\mathbf{a}-\mathbf{b}$ scale line $=10 \mu \mathrm{m}, \mathbf{c}-\mathbf{d}$ scale line $=5 \mu \mathrm{m}$ 

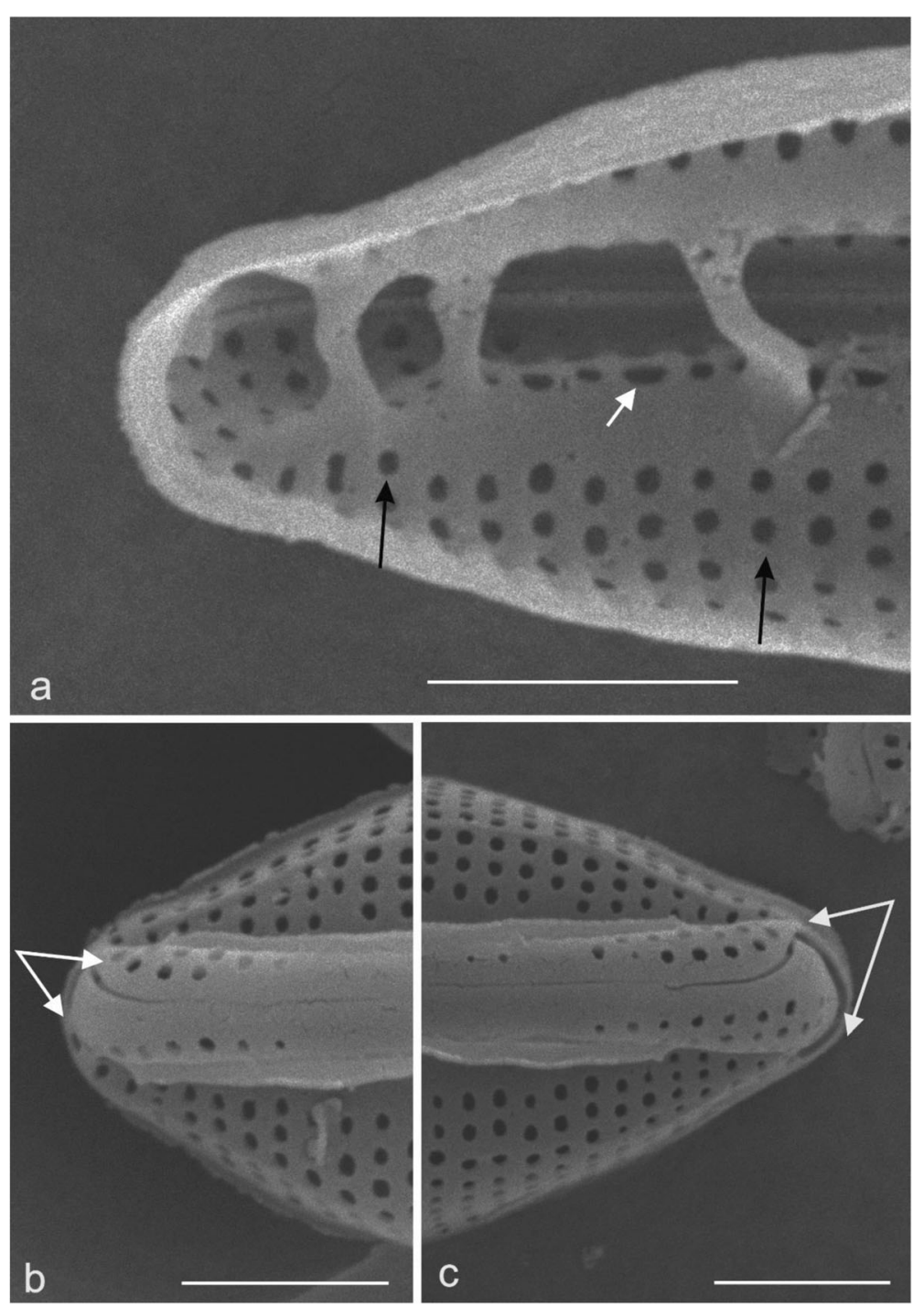

Fig. 3 Nitzschia volvendirostrata. a Internal view of the valve shows details of areolae and striae, b-c Apical raphe endings strongly bent in the same direction. Scale line $=1 \mu \mathrm{m}$

and electron microscopy. They were compared with Nitzschia volvendirostrata (Witkowski et al. 2016) and the validity of the name was verified on the website Algae-Base (Guiry and Guiry 2021).

\section{DNA extraction, PCR amplification and sequencing}

Cells at exponential stage were centrifuged at $1500 \mathrm{rpm}$ to obtain a pellet size of 100 to $200 \mu \mathrm{L}$ volume. The CTAB DNA extraction method (Doyle 1991; HerreraSepúlveda et al. 2015) was used to extract genomic DNA. We amplified two chloroplast genes ribulose bisphosphate carboxylase/oxygenase $(r b c L)$ and photosystem II CP43 protein $(p s b C)$ that were analyzed when $N$. volvendirostrata was described (Witkowski et al. 2016). The $r b c L$ gene was amplified as described by Lopez-Fuerte et al. (2020) and sequenced at Macrogen
(Seoul, South Korea) with the primers rbcL66 and rbcL1255 (Alverson et al. 2007). The $p s b C$ gene was amplified with 30 pico moles (pM) of primers psbC + and psbC857 (Alverson et al. 2007), $0.23 \mathrm{mM}$ dNTPs, 2 $\mathrm{mM} \mathrm{MgCl} 2,4 \mu \mathrm{L}$ of 10X PCR buffer, and 1.5 units $(\mathrm{U})$ of platinum Taq polymerase (InvitrogenTM). The PCR conditions were as follows: denaturation at $94{ }^{\circ} \mathrm{C}$ for $3 \mathrm{~min}$, followed by 35 cycles of $30 \mathrm{~s}$ at $94{ }^{\circ} \mathrm{C}, 50 \mathrm{~s}$ at $52{ }^{\circ} \mathrm{C}$, and $60 \mathrm{~s}$ at $72{ }^{\circ} \mathrm{C}$, with a final extension of $10 \mathrm{~min}$ at $72{ }^{\circ} \mathrm{C}$. Both strands of the amplified product of $p s b C$ were sequenced at Macrogen.

The obtained $r b c L$ and $p s b C$ sequences were edited in DNA Baser 4.5 programme (www.dnabaser.com) and were compared with DNA sequences in the GenBank database using the BLAST search to confirm the species identity of the diatom. We also performed 
Table 1 Diatom species used in the phylogenetic analysis with their strain information and the GenBank accession numbers of $r b c L$ and $p s b C$ sequences

\begin{tabular}{llll}
\hline Species & Strain & rbcL & psbC \\
\hline Nitzschia acicularis & Nit56 & MN734084 & MN734045 \\
Nitzschia aurariae & SZCZCH966 & KT943663 & KT943698 \\
Nitzschia capitellata & capitellata-Scot1 & FN557030 & MN734010 \\
Nitzschia draveillensis & Nit50 & MN734081 & MN734042 \\
Nitzschia filiformis & UTEX FD267 & HQ912453 & HQ912282 \\
Nitzschia frustulum & Nit25 & HF675070 & MN734040 \\
Nitzschia inconspicua & G6_1 & HF675102 & MN734024 \\
Nitzschia linearis & Nit53 & MN734083 & MN734044 \\
Nitzschia martiana & 3VIII07N. martyana & KJ577899 & KJ577933 \\
Nitzschia microcephala & R10 & MN734086 & MN734047 \\
Nitzschia pusilla & L3 & HF675109 & MN734029 \\
Nitzschia sigmoidea & BC0787 & MN718790 & MN718803 \\
Nitzschia varelae & NIT952CAT & KX889093 & MN734046 \\
Nitzschia volvendirostrata & SZCZP36 & KU179114 & KU179141 \\
Nitzschia volvendirostrata & KSA0039 & KU179112 & KU179139 \\
Nitzschia volvendirostrata & ClB 113 & MW627291 & MW627292 \\
Eunotia bilunaris & UTEX FD412 & HQ912463 & HQ912292 \\
Eunotia glacialis & UTEX FD46 & HQ912450 & HQ912279 \\
Eunotia sp. & ECT3676 & KC309552 & KC309623 \\
Eunotia pectinalis & NIES461 & HQ912500 & HQ912329 \\
\hline
\end{tabular}

phylogenetic analysis using Bayesian Inference (BI) in MrBayes 3.2.7a (Ronquist et al. 2012). Chloroplast $r b c L$ and $p s b C$ sequences of 16 species of Nitzchia and four species of Eunotia were included in the analysis (Table 1). Best fit model for the concatenated nucleotide sequences was selected based on AIC criterion using the jModeltest 2.1.10 (Guindon and Gascuel 2003; Darriba et al. 2012) and implemented in the Bayesian analysis. The BI was run for 10 million generations and a majority rule consensus tree was obtained.

\section{Results}

Specimens of our strain showed morphological characteristics (Figs. 2 and 3) very similar to the species $N$. volvendirostrata described by Witkowski et al. (2016) from Tofo sand in Mozambique, in the Indian Ocean and also from the Red Sea. Table 2 shows variations of morphometric characteristics compared to the type species reported by Witkowski et al. (2016).

Figure 2a shows several light microscope images of the strain $N$. volvendirostrata. Two plastids per cell were observed (Fig. 2b), similar to previous reports in other nitzschioid, one at each end of the cell (Lundholm and Moestrup 2000; Trobajo et al. 2013).
Table 2 Morphometric characteristics of $N$. volvendirostrata ( $N$ number of measurements, ND not determined)

\begin{tabular}{lll}
\hline & Witkowski et al. (2016) & This work \\
\hline Length $(\mu \mathrm{m})$ & $7-11.5$ & $7.5-14.1(N=30)$ \\
Width valve $(\mu \mathrm{m})$ & $3-3.5$ & $3.1-3.3(N=30)$ \\
Width frustule $(\mu \mathrm{m})$ & $\mathrm{ND}$ & $3.0-3.5(N=30)$ \\
Fibulae in $10 \mu \mathrm{m}$ & $8-9$ & $10-12(N=5)$ \\
Striae in $10 \mu \mathrm{m}$ & $52-54$ & $58-68(N=5)$ \\
Areolae in $10 \mu \mathrm{m}$ & $80-90$ & $70-100(N=5)$ \\
\hline
\end{tabular}

Frustules spindle shaped with elliptic or lanceolate form with rounded apices (Fig. 2c-d). The areolae are principally round (Figs. $2 \mathrm{c}-\mathrm{d}$ and $3 \mathrm{a}-\mathrm{c}$ ) and those in the raphe canal present shapes round to square (Figs. $2 \mathrm{c}$ and $3 \mathrm{a}$; white arrows). The uniseriate striae are parallel and transapical, they are present on both valves (Fig. 2c-d). The fibulae are irregularly distributed along the raphe canal, the central ones are bigger than apical (Fig. 2c; black arrows). The conopeum is clearly attached along the raphe (Fig. 2d; black arrows). The raphe is not interrupted by a space or central nodule (Fig. 2c; asterisk); the raphe endings are very hooked, a characteristic in other nitzschioid, both extreme sides bend towards one mantle like a hook and bend again towards the other mantle where it ends (Fig. 3b-c; white arrows).

For the two chloroplasts gene sequencing, we obtained a $1109 \mathrm{bp}$ fragment of the $r b c L$ gene and an $882 \mathrm{bp}$ of the $p s b C$ gene from the diatom strain CIB 113 (GenBank accession numbers: MW627291 and MW627292). Comparison of these sequences using BLAST search with the GenBank database sequences showed $100 \%$ similarity with the $r b c L$ sequence (KU179114) and $100 \%$ similarity with the $p s b C$ sequence (KU179141) of the $N$. volvendirostrata strain (SZCZP36) from Mozambique and 98.7\% (KU179112) and 99.1 \% (KU179139) similarity for the genes $r b c L$ and $p s b C$ respectively of the type species strain KSA0039 collected from Saudi Arabia (Witkowski et al. 2016). The BI phylogenetic analysis with the best fit model of concatenated nucleotide sequences, GTR $+\mathrm{I}+\mathrm{G}$ is presented in Fig. 4. It also confirms the identity of the isolated strain CIB 113 with a strong probabilities support $(100 \%)$ for the three $N$. volvendirostrata strains as a monophyletic group.

\section{Discussion}

The morphology of $N$. volvendirostrata registered in this work (Figs. 2 and 3) agree in general with those reported by Witkowski et al. (2016). The morphometry (Table 2) showed similar width but there were differences in the length (apical axis), that was somewhat longer, the fibulae and the striae density were higher, also a wider range in the areolae density. Those differences may be explained by the fact that the measured cells came from laboratory cultures; the culture conditions could be 


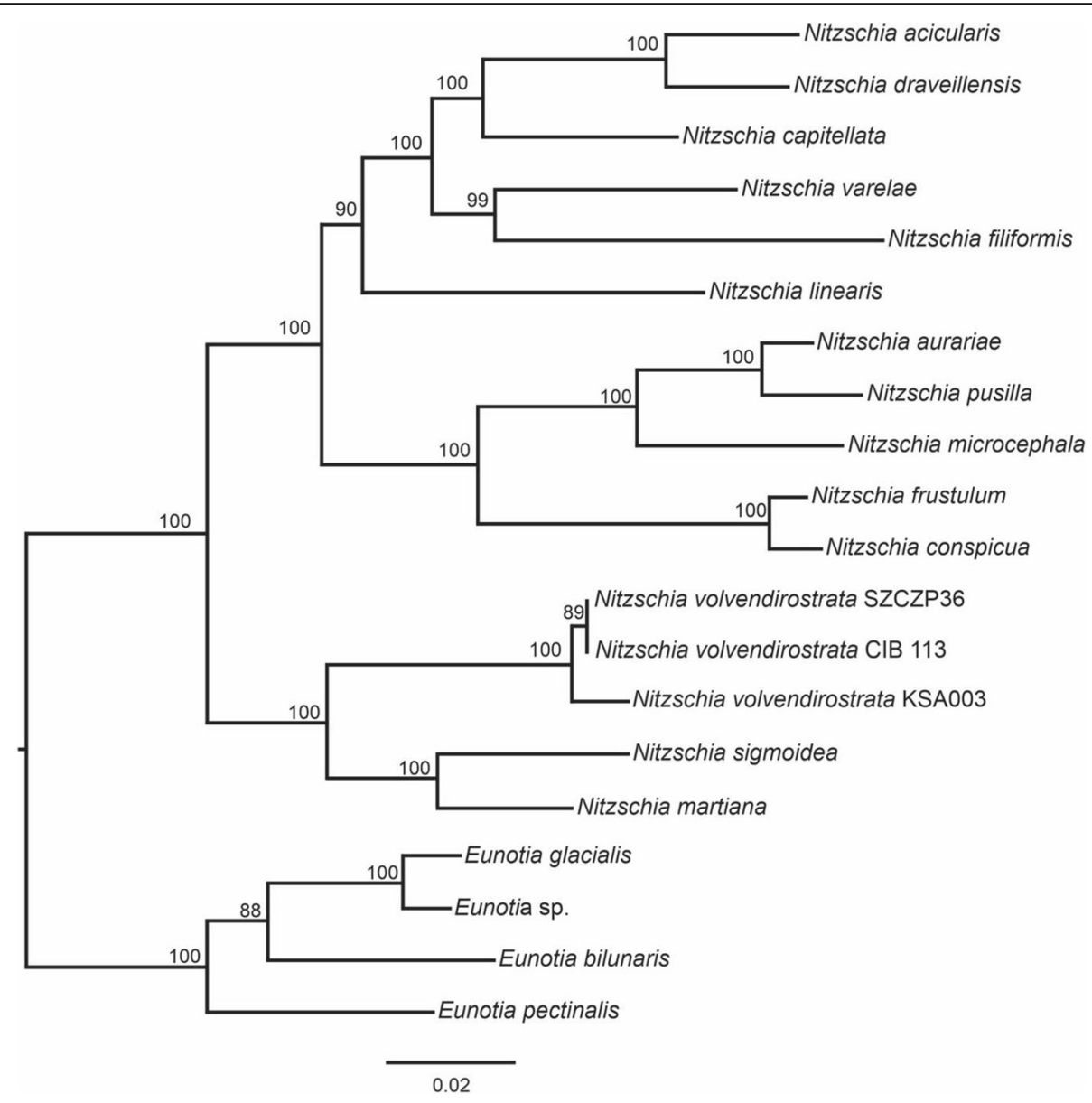

Fig. 4 Bayesian inference phylogenetic tree of Nitzschia species based on $r b c L$ and $p s b C$ sequences. The numbers at the nodes represent the percentage of posterior probabilities

different between Witkowski et al. (2016) and our study even though the culture medium $(\mathrm{f} / 2)$ was the same. The samples may also have been affected by the conditions (environment) where $N$. volvendirostrata was obtained. The biggest cells found in this work, and those mentioned by Witkowski et al. (2016) could also be part of a normal strategy of diatoms replication, to keep their form and size. Witkowski et al. (2016) pointed out the $N$. volvendirostrata cells sampled from the Yellow sea and the Tofo Sand along the Mozambique coast of the Indian Ocean, were identical in morphology but the cells from Red Sea were larger in size. However, based on molecular analysis Witkowski et al. (2016) placed the sample from Yellow sea as $N$. cf. volvendirostrata.

In this work the molecular tools showed a good match by BLAST from sequence comparison between the $r b c L$ and $p s b C$ sequences of our strain, and the strains of $N$. volvendirostrata KSA0039 from Saudi Arabia and the strain SZCZP36 from Mozambique (Witkowski et al. 2016) and the placement of the three strains as a monophyletic group in the phylogenetic tree (Fig. 4). The molecular analyses complemented the traditional taxonomy (morphology and morphometry) of the strain CIB 113.

Records of $N$. volvendirostrata are scarce (Fig. 1), as these were collected and identified from plankton net samples in Markaz Al Shoaibah (Al Qatan resort), Kingdom of Saudi Arabia $\left(20^{\circ} 50.47^{\prime} \mathrm{N}, 39^{\circ} 24.05^{\prime} \mathrm{E}\right)$ in 2013, from the samples of sediment (sand or mud), small gravel, rock scrape and seaweeds of Yellow sea, China and from the sand samples of Tofo Sand of Mozambique coast of Indian Ocean (Witkowski et al. 2016). This species was also registered from samples collected from nesting loggerhead sea turtles (Caretta caretta) (Kaleli et al. 2020) on the Dalyan beach, Aegean Sea, along the Turkish coast $\left(36^{\circ} 40.02^{\prime} \mathrm{N}, 28^{\circ} 41^{\prime} \mathrm{E}\right)$. The Red Sea and Mozambique coast are tropical whilst the others are temperate. In accordance to the samples where $N$. volvendirostrata was found, it seems it is a microbenthic raphid pennate that can live on different substrates inorganic, seaweeds or animals and also as phytoplankter.

Ours is the first register of $N$. volvendirostrata along the American continent, which not only supports the 
suggestion of Witkowski et al. (2016) on the global distribution of this benthic diatom, but also supports the hypothesis of their ubiquity (Finlay 2002). Due to this, allopatric speciation would be rare in this species and also would explain the high level of similarity in the morphological characteristics between the strains.

\section{Conclusions}

We could identify the species by our integrated approach: culture, morphological and molecular analyses. With this first record along the Mexican Pacific coast, we expand the geographic range of $N$. volvendirostrata to along the American continent, and also support the ubiquity hypothesis for this taxon.

\section{Acknowledgements \\ We thank to James M. Ehrman, Digital Microscopy Facility in Mount Allison University, for the SEM images taken, Marte Virgen Félix technician of the Culture Collection of Microalgae for N. volvendirostrata supply, Eileen Glazier for the English review of this manuscript and Joaquín Rivera Rosas for help drawing the maps. FOLF thanks the support of PRODEP and SNI-CONACYT programs. We also thank the unknown reviewers for their suggestions and comments.}

\section{Authors' contributions}

MCLV sampled, isolated, cultured and maintained the strain, took the light microscopy images of living cells, wrote the first draft and the final edition with the contributions of GM and FOLF. GM performed and interpreted the molecular analysis, FOLF proposed the work, identified the taxon, made the analysis of images and organized the figures. All authors reviewed and approved the final manuscript.

\section{Funding}

20367 and 10024 CIBNOR internal projects.

\section{Availability of data and materials}

The datasets used and/or analyzed during the current study are available from the corresponding author on reasonable request.

\section{Declarations}

Ethics approval and consent to participate

Not applicable.

\section{Consent for publication}

Not applicable.

\section{Competing interests}

The authors declare that they have no competing interests.

\section{Author details}

${ }^{1}$ Centro de Investigaciones Biológicas del Noroeste S. C. Av. Instituto Politécnico Nacional 195, Playa Palo de Santa Rita Sur, La Paz, Baja California Sur, México C.P. 23096. ${ }^{2}$ Departamento Académico de Ciencias Marinas y Costeras, Universidad Autónoma de Baja California Sur, Carretera al Sur, km. 5.5, La Paz, Baja California Sur, México C.P. 23080.

Received: 10 February 2021 Accepted: 11 August 2021

Published online: 23 August 2021

\section{References}

Alverson AJ, Jansen RK, Theriot EC. Bridging the Rubicon: phylogenetic analysis reveals repeated colonizations of marine and fresh waters by thalassiosiroid diatoms. Mol Phylogenet Evol. 2007;45(1):193-210.

Blanco S. Diatom taxonomy and identification keys. In: Cristóbal G, Blanco S, Bueno G, editors. Modern trends in diatom identification fundamentals and applications. Switzerland: Springer Nature; 2020. p. 25-38.
Darriba D, Taboada GL, Doallo R, Posada D. jModelTest 2: more models, new heuristics and parallel computing. Nat Methods. 2012;9:772.

Doyle JA. DNA Protocols for Plants. In: Hewitt GM, Johnston AWB, Young JPW, editors. Molecular Techniques in Taxonomy. NATO ASI Series (Series H: Cell Biology), vol 57. Heidelberg: Springer; 1991. p. 283-93.

Finlay BJ. Global dispersal of free-living microbial eukaryote species. Science. 2002;296(5570):1061-3.

Guillard RRL. Culture of phytoplankton for feeding marine invertebrates. In: Smith WL, Chanley MH, editors. Culture of marine invertebrate animals. Boston: Springer; 1975 . p. 26-60.

Guindon S, Gascuel O. A simple, fast, and accurate algorithm to estimate large phylogenies by maximum likelihood. Syst Biol. 2003;52(5):696-704.

Guiry MD, Guiry GM. AlgaeBase. World-wide electronic publication, National University of Ireland, Galway. http://www.algaebase.org. Accessed 22 Jan 2021.

Herrera-Sepúlveda A, Medlin LK, Murugan G, Sierra-Beltrán AP, Cruz-Villacorta AA, Hernández-Saavedra NY. Are Prorocentrum hoffmannianum and Prorocentrum belizeanum (Dinophyceae, Prorocentrales), the same species? An integration of morphological and molecular data. J Phycol. 2015;51(1):173-88.

Kaleli A, Car A, Witkowski A, Krzywda M, Riaux-Gobin C, Solak CN, et al. Biodiversity of carapace epibiont diatoms in loggerhead sea turtles (Caretta caretta Linnaeus 1758) in the Aegean Sea Turkish coast. PeerJ. 2020:8:e9406.

López-Fuerte FO, Siqueiros-Beltrones DA. Halamphora primus (Bacillariophyta): a new diatom species from the Gulf of California, Mexico. Phytotaxa. 2018; 369(4):287-94.

López Fuerte FO, Siqueiros Beltrones DA, Navarro JN. Benthic diatoms associated with mangrove environments in the northwest region of México. 1st ed. La Paz: R Comisión Nacional para el Conocimiento y Uso de la Biodiversidad (CONABIO). DR Universidad Autónoma de Baja California Sur; 2010.

López-Fuerte FO, Sala SE, Lora-Vilchis MC, Murugan G. Halamphora siqueirosii Bacillariophyta), a new diatom species isolated from a hypersaline evaporation pond in Baja California Peninsula, Mexico. Phytotaxa. 2020;451(2): $132-44$.

Lowe RL. Keeled and canalled raphid diatoms. In: Wehr JD, Sheath RG, Kociolek P editors. Freshwater algae of North America Ecology and Classification. San Diego: Academic Press; 2003. pp. 669-84.

Lundholm N, Moestrup JO. Morphology of the marine diatom Nitzschia navisvaringica, sp. nov. (Bacillariophycea), another producer of the neurotoxin domoic acid. J Phycol. 2000;36(6):1162-74.

Mann DG. Nitzschia subgenus Nitzschia. Notes for a monograph of the Bacillariaceae. In: Ricard M, editor. Proceeding of the 8th International Diatom Symposium. Königstein: Koeltz Scientific Books; 1986. p. 215-26.

Medlin LK. Mini review: Diatom species as seen through a molecular window. Rev Braz Bot. 2018:41(2):457-69.

Ronquist F, Teslenko M, van der Mark P, Ayres DL, Darling A, Höhna S, Larget B, Liu L, Suchard MA, Huelsenbeck JP. MrBayes 3.2: efficient Bayesian phylogenetic inference and model choice across a large model space. Syst Biol. 2012;61(3):539-42.

Scholz B, Liebezeit G. Screening for competition effects and allelochemicals in benthic marine diatoms and cyanobacteria isolated from an intertidal flat (southern North Sea). Phycologia. 2012;51:432-50.

Scholz B, Liebezeit G. Compatible solutes and fatty acid composition of five marine intertidal microphytobenthic Wadden Sea diatoms exposed to different temperature regimes. Diatom Res. 2013;28(4):337-58.

Siqueiros Beltrones DA, Martínez-Hernández YJ, Aldana-Moreno A. Florística exploratoria de diatomeas epifitas en Rhodophyta de Islas Revillagigedo. Cymbella. 2019:5(1):98-123.

Trobajo R, Rovira L, Ector L, Wetzel CE, Kelly M, Mann DG. Morphology and identity of some ecologically important small Nitzschia species. Diatom Res. 2013;28:37-59.

Witkowski A, Li Ch, Zglobicka I, Yu SX, Ashworth M, Dąbek P, et al. Multigene assessment of biodiversity of diatom (Bacillariophyceae) assemblages from the littoral zone of the Bohai and Yellow Seas in Yantai Region of northeast China with some remarks on ubiquitous taxa. J Coast Res. 2016;74(Sp1):16695.

\section{Publisher's Note}

Springer Nature remains neutral with regard to jurisdictional claims in published maps and institutional affiliations. 